\title{
norden
}

\section{Behöver den nordiska modellen förändras?}

Huvuddragen från forskningsrapporten The Nordic model - challenged but capable of reform

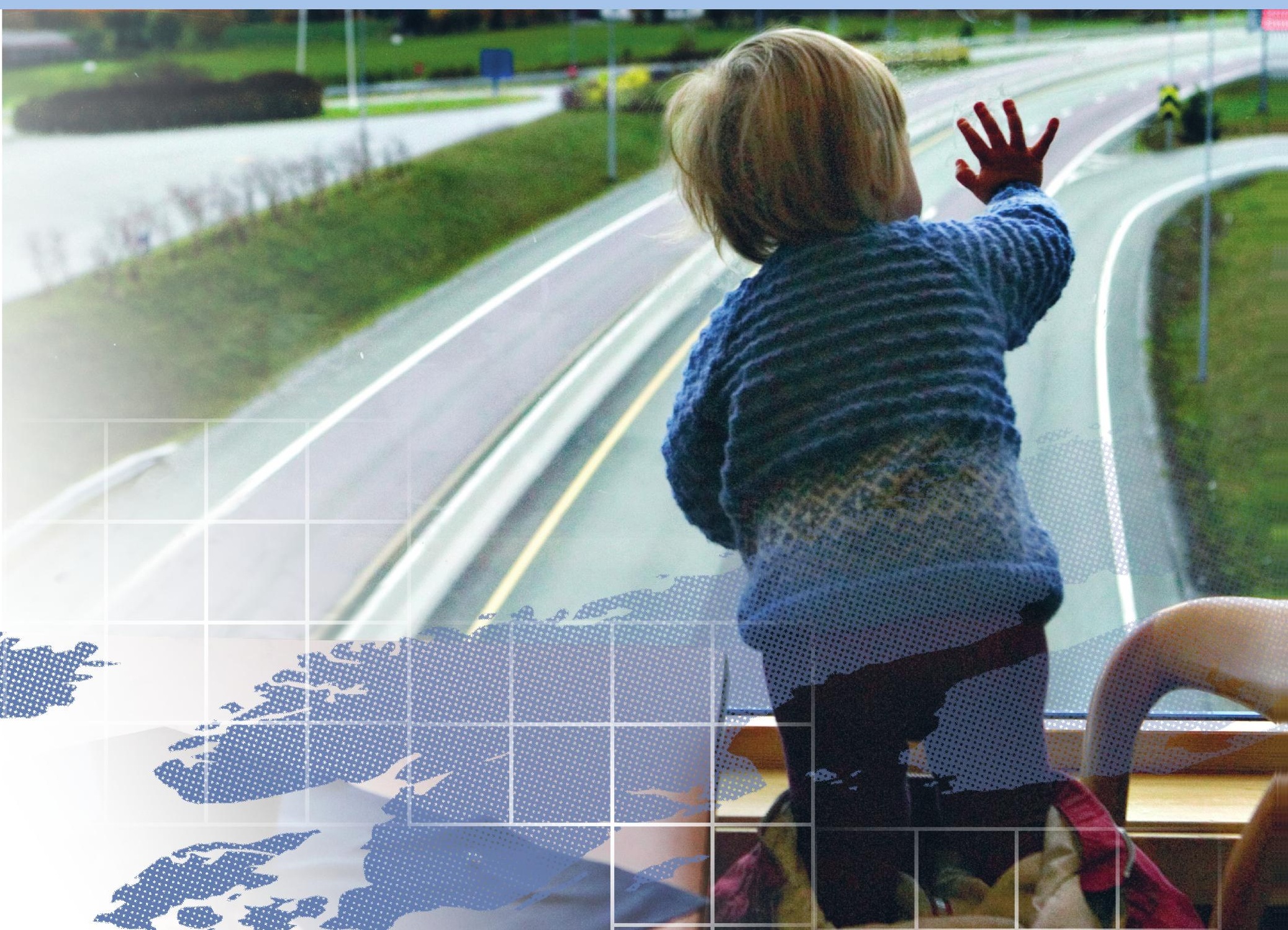




\section{Behöver den nordiska modellen förändras?}

Huvuddragen från forskningsrapporten The Nordic model - challenged but capable of reform

ISBN 978-92-893-2814-2

http://dx.doi.org/10.6027/ANP2014-734

ANP 2014:734

(C) Nordiska ministerrådet 2014

Produktion och text: Arvidsson Kultur\&Kommunikation, Malmö

Bidrag till ursprungsrapporten The Nordic model

- challenged but capable of reform:

Tarmo Valkonen and Vesa Vihriälä (Redaktörer) Författare: Karsten Albæk, Torben M. Andersen, Rita Asplund, Erling Barth, Bernt Bratsberg, Lars Calmfors, Antti Kauhanen, Jukka Lassila, Mika Maliranta, Niku Määttänen, Oddbjørn Raaum, Knut Røed, Kristine von Simson, Allan Sørensen, Tarmo Valkonen, Pekka Vanhala and Vesa Vihriälä Layout: Erling Lynder Omslagsfoto: Karin Beate Nøsterud/norden.org Tryck: Rosendahls-Schultz Grafisk Upplaga: 1000

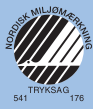

www.norden.org/sv/publikationer

\section{Printed in Denmark}

Denna rapport är utgiven med finansiellt stöd från Nordiska ministerrådet. Innehållet i rapporten avspeglar inte nödvändigtvis Nordiska ministerrådets synpunkter, åsikter eller rekommendationer.

\section{Nordiska ministerrådet}

Ved Stranden 18

DK-1061 København K

Telefon (+45) 33960200

www.norden.org

\section{Det nordiska samarbetet}

Det nordiska samarbetet är ett av världens mest omfattande regionala samarbeten. Det omfattar Danmark, Finland, Island, Norge och Sverige samt Färöarna, Grönland och Åland.

Det nordiska samarbetet är politiskt, ekonomiskt och kulturellt förankrat och är en viktig partner i europeiskt och internationellt samarbete. Den nordiska gemenskapen arbetar för ett starkt Norden i ett starkt Europa.

Det nordiska samarbetet ska stärka nordiska och regionala intressen och värderingar i en global omvärld. Gemensamma värderingar länderna emellan bidrar till att stärka Nordens ställning som en av världens mest innovativa och konkurrenskraftiga regioner. 


\section{Behöver den nordiska modellen förändras?}

I denna publikation finns huvuddragen

från forskningsrapporten The Nordic model

- challenged but capable of reform.

Förord 5

$\begin{array}{ll}\text { Den nordiska modellen } & 7\end{array}$

$\begin{array}{ll}\text { De tre utmaningarna } & 10\end{array}$

Framtidsvägar och utvecklingsmodeller $\quad 15$

De nordiska ländernas svagheter och styrkor samt förslag till åtgärder 20

$\begin{array}{ll}\text { Slutord } & 22\end{array}$ 


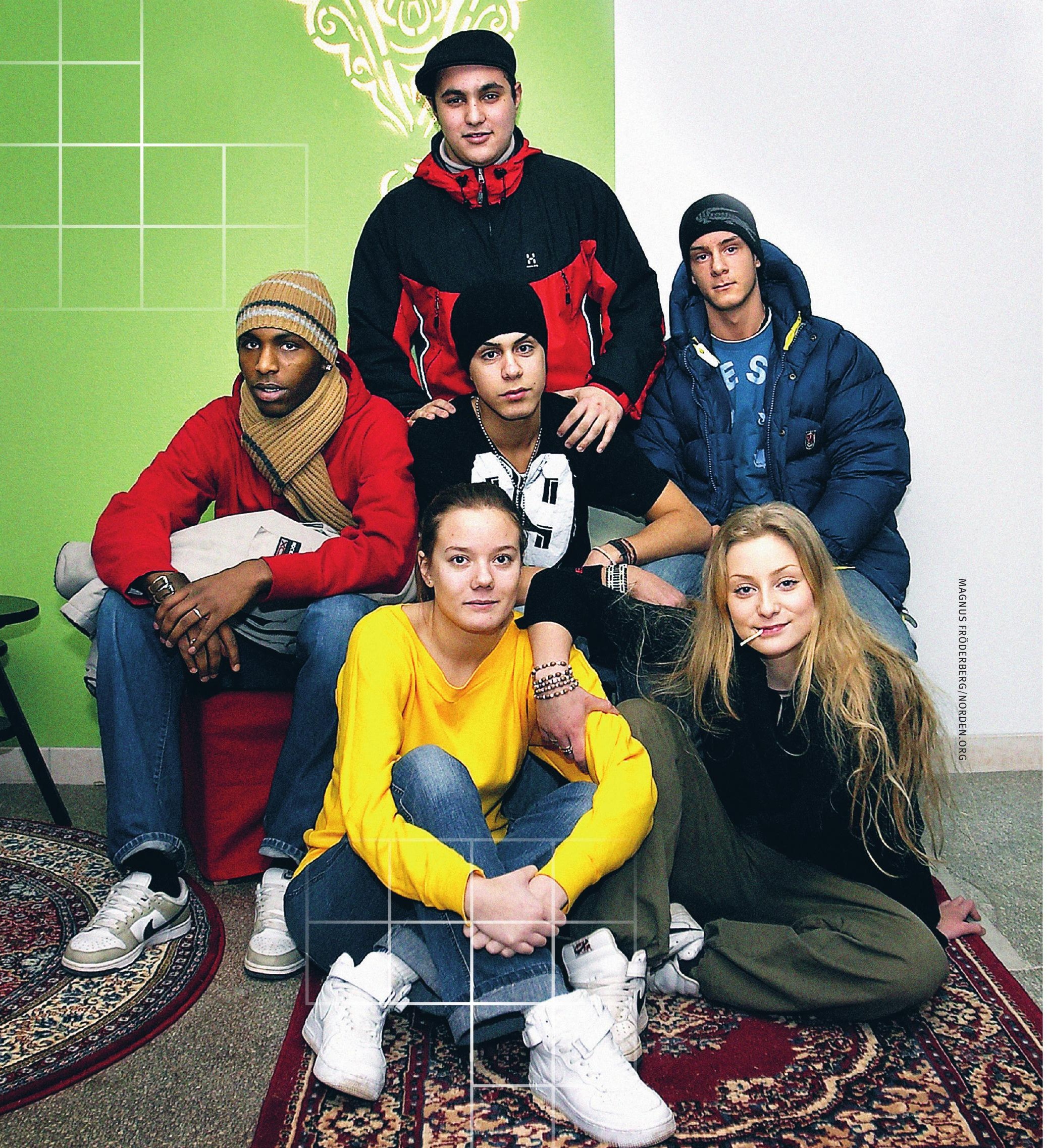




\section{Förord}

Den skrift du håller i din hand är ett kortfattat och fritt hållet koncentrat av ett omfattande forskningsprojekt om den nordiska modellen och dess hållbarhet $\mathrm{i}$ framtiden.

Finns den nordiska modellen? Vilka utmaningar står den inför? Och kan den reformeras för att bättre stå emot samhällsförändringarna sett $i$ ett globalt perspektiv. Huvudrapporten "The Nordic model - challenged but capable of reform" är en del i programmet
"Hållbar nordisk välfärd", finansierat av Nordiska ministerrådet, på initiativ av de nordiska arbetsgivarorganisationerna. Avsikten med forskningsrapporten är att ge de nordiska regeringarna verktyg för att klara de välfärdsutmaningar som de nordiska länderna kommer att ställas inför.

Det är ETLA, Research Institute of the Finnish Economy, som i samarbete med andra forskare och universitet i Norden har tagit fram rapporten.
Vi hoppas att denna kortversion och den djuplodande huvudrapporten ska ge inspiration till en nordisk debatt i välfärdsfrågorna, men också bidra till den internationella debatten där intresset för Norden och våra välfärdssystem är omfattande.

Dagfinn Høybråten Generalsekreterare Nordiska ministerrådet 
Under de senaste åren har det talats mycket om den nordiska modellen. I ansträngningarna att hantera följderna av den globala finansiella och ekonomiska krisen har de nordiska länderna framhållits som särskilt framgångsrika. De har till och med ansetts ha ett efterföljansvärt samhällskoncept för andra länder. Den harmoniska kombinationen av en omfattande välfärdsstat, välskötta statsfinanser och en välfungerande marknadsekonomi har gjort att modellen fått epitet "The next supermodel" av tidskriften The Economist. I denna fristående publikation finns huvuddragen från forskningsrapporten The Nordic model - challenged but capable of reform. Här ger nordiska forskare sin syn på den nordiska modellen och dess utmaningar och möjliga anpassning till kommande år. 


\section{Den nordiska modellen}

Till trots för det goda globala ryktet står Norden inför många problem och utmaningar. Även om man klarat sig relativt bra har finanskrisen också drabbat de nordiska länderna. Frågan är om den nordiska modellen i alla aspekter verkligen varit den succé den ofta beskrivs som. Kan man återupprepa dessa framgångar i framtiden, eller är modellen otillräcklig och bristfällig i globaliseringens tidevarv?

Och vad är det egentligen som är så unikt i den nordiska modellen, vad är det man talar om?

Den traditionella bilden av den nordiska modellen är en välfärdsstat som kännetecknas av en stor offentlig sektor som förser sina medborgare med generösa bidrag, välfärdstjänster och ett socialt skyddsnät. Samtidigt har länderna varit måna om att upprätthålla sunda statsfinanser. Arbetsmarknaden regleras i hög grad av kollektivavtal. Utbildning är kostnadsfri och håller för det mesta hög kvalitet och mycket skattemedel satsas på forskning och utveckling. De nordiska län- derna har varit öppna för frihandel och teknologiska förändringar. Man har vidare uppnått en hög levnadsstandard, höga sysselsättningsnivåer, relativt låga inkomstskillnader och en hög nivå på jämställdhet. Stämmer

\section{Den traditionella bilden} av den nordiska modellen är en välfärdsstat som kännetecknas av en stor offentlig sektor som förser sina medborgare med generösa bidrag, välfärdstjänster och ett socialt skyddsnät.

denna bild med verkligheten? Här följer en genomgång för att se om denna bild kan bekräftas genom att jämföra data från de nordiska länderna med andra europeiska länder samt USA.

Norden har kunnat behålla höga BNP per capita-nivåer, och överträffas här som grupp endast av USA. En titt på inkomstfördelningen bekräftar också att detta välstånd alltjämt är relativt jämlikt fördelat bland befolkningen. Inkomstskillnaderna är låga - här bildar länderna en tydligt urskiljbar grupp i Europa. De enda som kommer i närheten av Norden är Tyskland, Frankrike, Nederländerna, Österrike och Belgien.

En hög sysselsättningsgrad kännetecknar Norden, det är i synnerhet kvinnor och äldre som bidrar till att andelen är hög. Det finns dock vissa skillnader mellan länderna - Finland och Danmark hamnar efter de övriga. Arbetsmarknaderna kännetecknas av en "flexicurity"-modell med relativt sett liberala anställningsvillkor och fokus på aktiveringsåtgärder för arbetslösa. Vad gäller fackföreningarnas relativt starka ställning är nästan 70 procent av de nordiska arbetstagarna anslutna, vilket är en mycket högre siffra än någon annanstans. Däremot är andelen arbetstagare som är täckta av kollektivavtal inte högre än i många andra europeiska länder.

Bilden av att mycket resurser spenderas på forskning och ut- 
veckling stämmer med verkligheten. Detta gäller särskilt Sverige och Finland.

Sunda statsfinanser har framhållits som en viktig faktor för att förklara varför finanskrisen blev mindre allvarlig i de flesta nordiska länderna. Alla länder utom Island har kunnat upprätthålla hanterbara skuldnivåer; de är bland de allra lägsta i Europa. Det är dock svårt att hitta belägg för att det kan förklaras med en likartad politik i de nordiska länderna.

\section{De nordiska länderna} ligger $\mathrm{i}$ topp vare sig man mäter tillit till andra människor, politiker eller rättssystem.

Är då den offentliga sektorn i de nordiska staterna särskilt stor? Det som talar för detta är att en stor andel av befolkningen är anställd inom den offentliga sektorn, och att man fortfarande har något större skatteintäkter i förhållande till BNP i jämförelse med andra länder. Å andra sidan skiljer man sig inte längre från många andra länder i Europa vad det gäller andra faktorer som offentliga utgifter och nivån på arbetslöshetsersättningar. Särskilt överraskande är att omfördelning genom skatter och transfereringar inte sticker ut, även om detta förmodligen kan förklaras med att de höga nordiska sysselsättningsnivåerna reducerar behovet av sådana åtgärder. Länderna skiljer sig också en hel del inbördes vad gäller dessa faktorer. Island har den minsta offentliga sektorn med hänsyn till både skattenivån och andelen av den offentliga sektorns sysselsättning, medan Norge och Sverige har lägre nivåer på bidrag än de andra.

\section{Tilliten- enastående i världen}

Det ska dock poängteras att det finns ett område där Norden alldeles speciellt utmärker sig - den höga graden av tillit. De nordiska länderna ligger i topp vare sig man mäter tillit till andra människor, politiker eller rättssystem.

Man kan alltså konkludera att det fortfarande finns fog för att tala om en speciell nordisk modell. Låga inkomstskillnader, jämställdhet, goda institutioner och den höga allmänna tilliten skapar goda mänskliga förutsättningar för ett välfungerande samhälle, där kombinationen av utbyggda sociala skyddsnät och en dynamisk marknadsekonomi utgör den yttre ramen.

\section{Tilliten en tillgång men Norden inte fullt så unikt}

Norden är dock inte fullt så unikt i Europa som det en gång var. Dels finns det skillnader inbördes mellan de nordiska länderna, dels uppvisar Norden stora likheter med andra europeiska länder på vissa områden. Även om Norden fortfarande karaktäriseras av en stor offentlig sektor i kombination med höga skattenivåer så är det inte längre så specifikt nordiskt. Här finns stora likheter med länder som Frankrike, Tyskland och Nederländerna.

Den nordiska modellen har framstått i olika ljus under skilda tider. Efter en lysande period under efterkrigstiden genomgick de nordiska ekonomierna en mör- 


\section{De tre utmaningarna}

Den nordiska modellen utmanas redan nu och kommer i framtiden sannolikt att än mer utmanas av tre megatrender: den digitala revolutionen, globaliseringen och den stigande medellivslängden.

\section{Den digitala revolutionen}

Den alltmer kraftfulla digitala teknologin kan innebära att en stor del av dagens arbetsplatser försvinner. Det är snart inte längre

\section{Analyser pekar på att vart tredje, eller kanske till och med vartannat jobb är hotat under de närmaste tio till tjugo åren.}

bara de enkla rutinmässiga arbetena som är hotade, utan även arbeten som fordrar avancerad yrkesskicklighet. Analyser pekar på att vart tredje, eller kanske till och med vartannat jobb är hotat under de närmaste tio till tjugo åren. Den privata sektorn är i det här sammanhanget mer sårbar än den offentliga. Det är mest lågoch medelinkomstarbeten som kommer att försvinna medan de nya jobb som skapas antingen är på den övre delen av löneskalan eller på den lägsta nivån. De som får fördelar av förändringarna är de som äger eller behärskar den nya teknologin. Nya servicearbeten kommer visserligen att skapas men dessa arbeten är sällan välbetalda. Det är alltså troligt att den polarisering av arbetsmarknaden som redan idag kan observeras i många länder kommer att fortsätta. Inkomstskillnaderna i samhället kommer att öka alltmer vilket kommer att få sociala konsekvenser och riskerar att påverka den samhälleliga tilliten negativt.

\section{Globaliseringen}

Att ha en stor offentlig sektor och därmed ett högt skattetryck blir allt svårare då nationsgränser betyder allt mindre och företag och människor blir alltmer lättrörliga. Företag väljer att förlägga huvudkontor och verksamhet $\mathrm{i}$ länder där kostnadsbilden är förmånligast. En ökande del av produktionen sker i internationella värdekedjor som kontrolleras av transnationella företag. Företagen kan finjustera sina skattekostnader genom att förlägga valda delar av sin produktion i länder

Företagen kan finjustera sina skattekostnader genom att förlägga valda delar av sin produktion $\mathbf{i}$ länder med lägst skatt.

med lägst skatt. Många nordiska företag har redan idag den största delen av sin personalstyrka utanför sina hemländer. Även den högkvalificerade arbetskraften blir alltmer rörlig. Existensen av globala företag och nätverk, förbättrade språkkunskaper, likartade utbildningar och livsstilar gör människor allt mindre bundna till ett enskilt land. Konkurrensen mellan länderna ökar alltmer och stora ansträngningar görs på nationell nivå för att locka företag och kvalificerad arbetskraft, inte minst vad det gäller sänkta skattenivåer. Att hålla företagens kostnadsnivå konkurrenskraftig samtidigt som goda livsbetingelser för den kvalificerade arbets- 
- SHOW BUSINESS

- NETUDRK

$-M \cup S I C$

- CINEMA

- BUSINESS/FINANEE

- WDRDNEWS
12010111010101001

0010101010100101

11010101110010101

111110110110101110110

101101010101101

11111110001010111111011010

1011010111

10101110101101011010

01100111111010

111111010101011010101

0110101011111111
12010111010101001

110101011100101011

1101010020011011

111110110110101110110 101101010101101

11111110001010111111011010 1011010111

101011101011010110101

011001111110101

0110101011111111

\section{0}

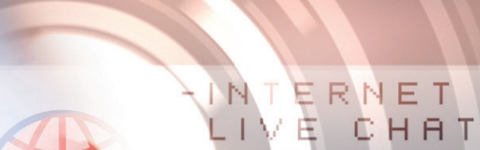
LI E D : H T T M P ง 1 口曰
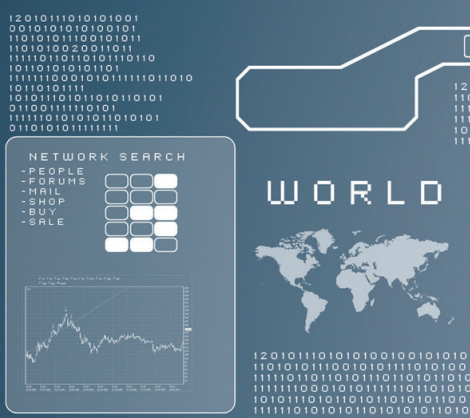

\begin{tabular}{l|l}
\hline \hline \\
\hline
\end{tabular}
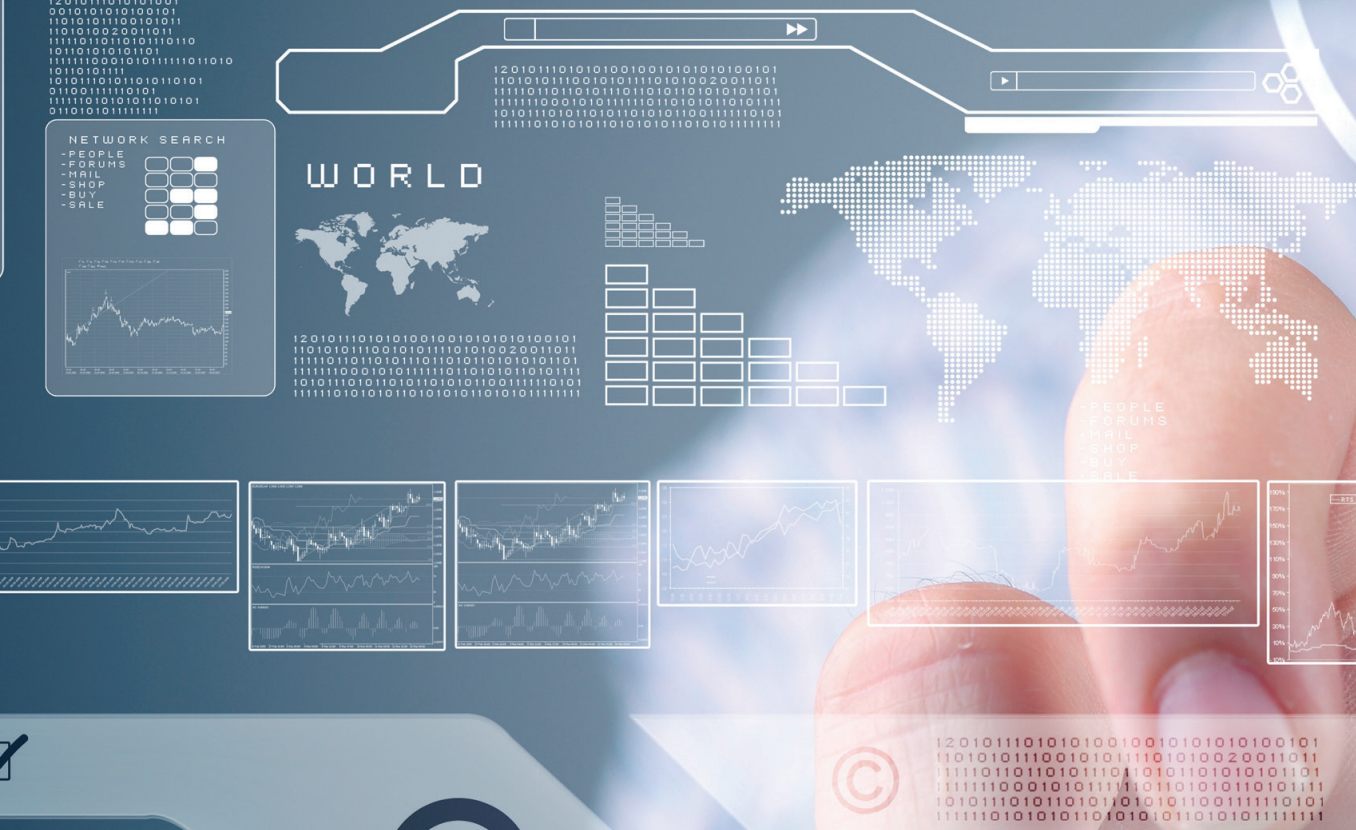

\section{?}
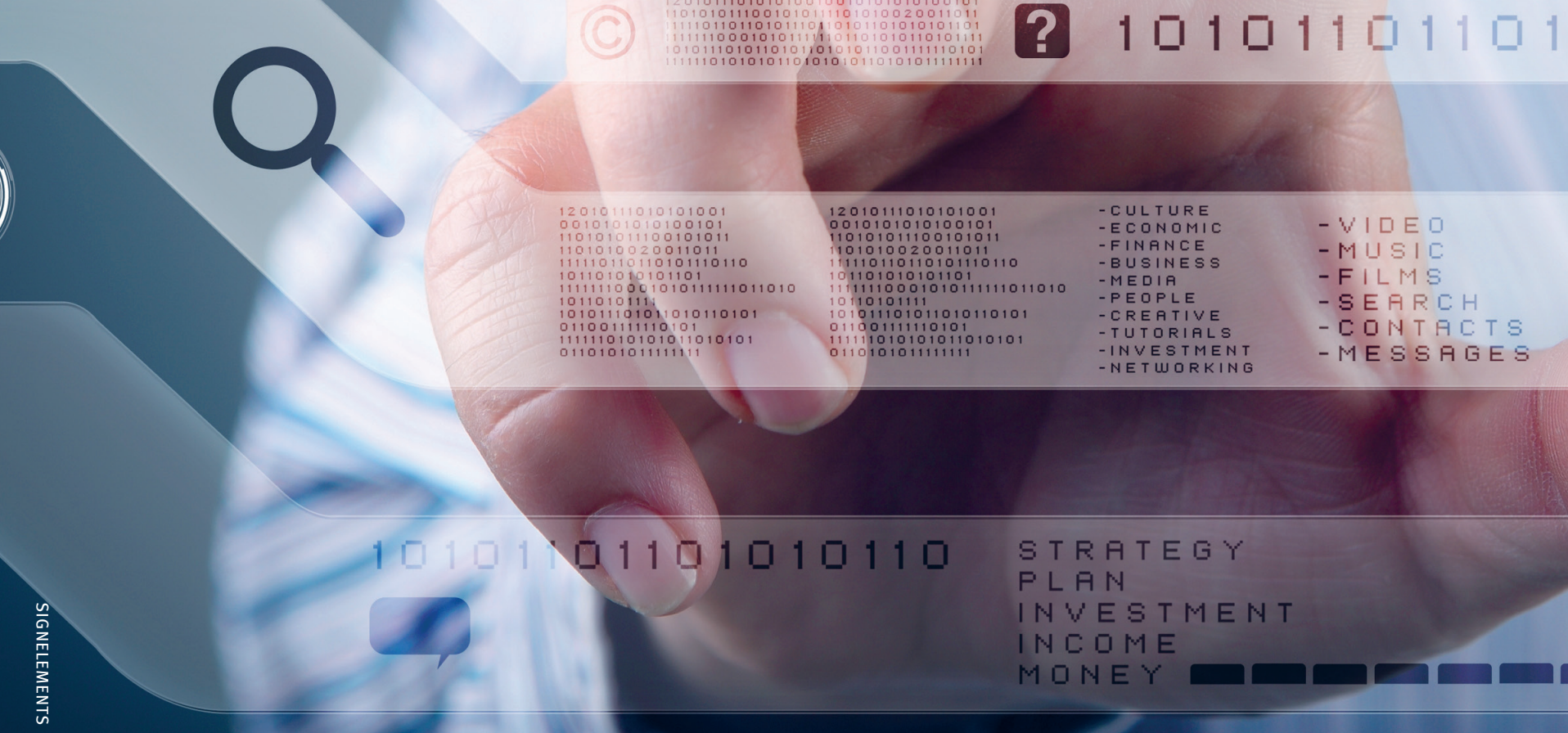

STRATEGY

PLAN

IN VESTMENT

INCDME

$M \square N E Y$

- w I E ए

$-M \amalg S \mid \mathrm{C}$

- FIL MS

- SEARE:

- CONTACTS

- MESSAGES

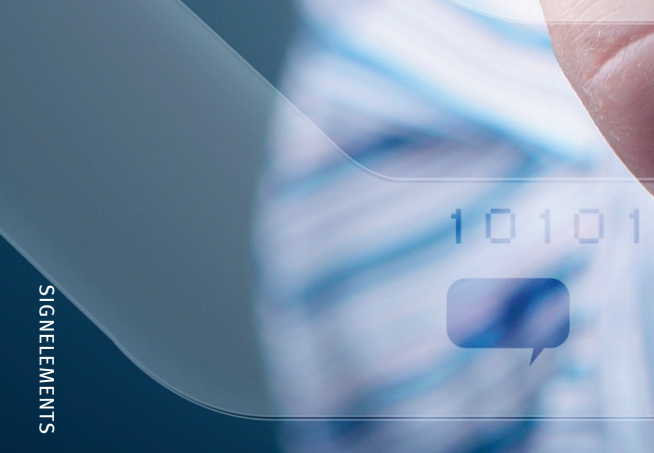


kraften skapas och upprätthålls är därför nyckelfaktorer för att kunna behålla produktion inom de nordiska länderna.

\section{Den stigande medellivslängden}

Medellivslängden fortsätter att öka. Den kantring som befolkningspyramiden därmed uppvisar kompenseras inte fullt ut $i$ andra änden vare sig av stigande fertilitet eller ökad invandring. Resultatet blir att den del av befolkningen som är i arbetsför ålder minskar. Eller för att uttrycka det tvärtom: beroendetalet ökar. Allt färre måste försörja den åldrande befolkningen. Detta

\section{Allt färre måste försörja den åldrande befolkning- en. Detta skapar ett ökat tryck på de offentliga} finanserna.

skapar ett ökat tryck på de offentliga finanserna. Utmaningen blir särskilt stor för de nordiska välfärdsmodellerna med sina generösa transfereringssystem. Här är traditionen att den offentliga sektorn ska vara heltäckande i uppgiften att ta hand om äldre, sjuka och sårbara i samhället. Dessutom försvåras situationen om vissa befolkningsgrupper står utanför arbetsmarknaden och har svårt att finna produktiv sysselsättning.

Två faktorer gör de nordiska länderna särskilt sårbara för dessa tre ovannämnda globala trender. Dels är förväntningarna på att staten ska förse medborgarna med välfärdstjänster djupt förankrad i de nordiska samhällena, något som gör att kostnaderna för detta förväntas öka. Detta beror för det första på den så kallade Wagner-effekten, som pekar på att efterfrågan på offentliga tjänster som andel av BNP ökar när en ekonomi utvecklas och BNP stiger. Den andra effekten kallas Baumols sjuka, som visar att kostnaden för välfärdstjänster utgör en ökande andel av BNP eftersom produktiviteten inom serviceyrken utvecklas långsammare än inom varuproduktion. Dessutom är de nordiska ekonomierna små öppna ekonomier som är känsliga för chocker inom sina högspecialiserade exportindustrier. En nedgång kan bli svår att hämta sig från, något som framförallt Finland fått erfara under den senaste krisen.

En hög kompetensnivå har varit starkt bidragande till de nordiska ländernas höga produktivitet. Därför är de brister som utbildningssystemen uppvisar både på låg och hög nivå oroande. PISA-resultaten är mycket nedslående i Norden med Finland som markant undantag. När det gäller nordiska universitet är det inte många som placerar sig högt på internationella rankningslistor. Av de femtio högst rankade universiteten i en kinesisk rankning från 2013 så var bara två nordiska: Köpenhamns universitet på 42:a

Inom vårdsektorn blir fler och fler sjukdomar behandlingsbara och alltfler kostsamma medicinska tekniker utvecklas. Vem ska få vård? Vem ska betala? 


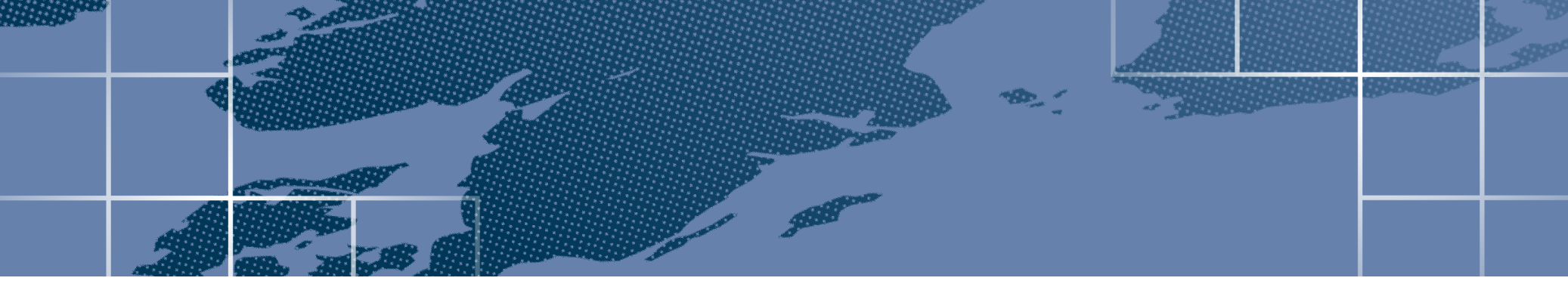

plats och Karolinska institutet i Stockholm på 44:e plats. Dessa brister i utbildningssystemen hotar att urholka arbetskraftens kompetens och produktivitet. Stora samhällsgrupper med bristfällig utbildning står dessutom inför risken att lättare hamna i arbetslöshet, få dålig hälsa och i förlängningen bli beroende av socialt understöd.

Inom vårdsektorn blir fler och fler sjukdomar behandlingsbara och alltfler kostsamma medicinska tekniker utvecklas. Vem ska få vård? Vem ska betala? I många länder läggs bördan av dessa ökade kostnader direkt på individerna. Den modellen är svår att genomföra i de nordiska länderna då vi har en lång historia av allmän och jämlik tillgång till vård. Den nordiska modellens kanske allra största styrka, befolkningens tillit till de offentliga systemen, riskerar att undermineras om förmågan att tillhandahålla högkvalitativ vård och omsorg inte kan upprätthållas.
I ett nötskal: kraven på offentliga skyddsnät och tjänster ökar medan det blir allt mindre utrymme för skatteuttag, då skattebaserna blir alltmer flyktiga. 


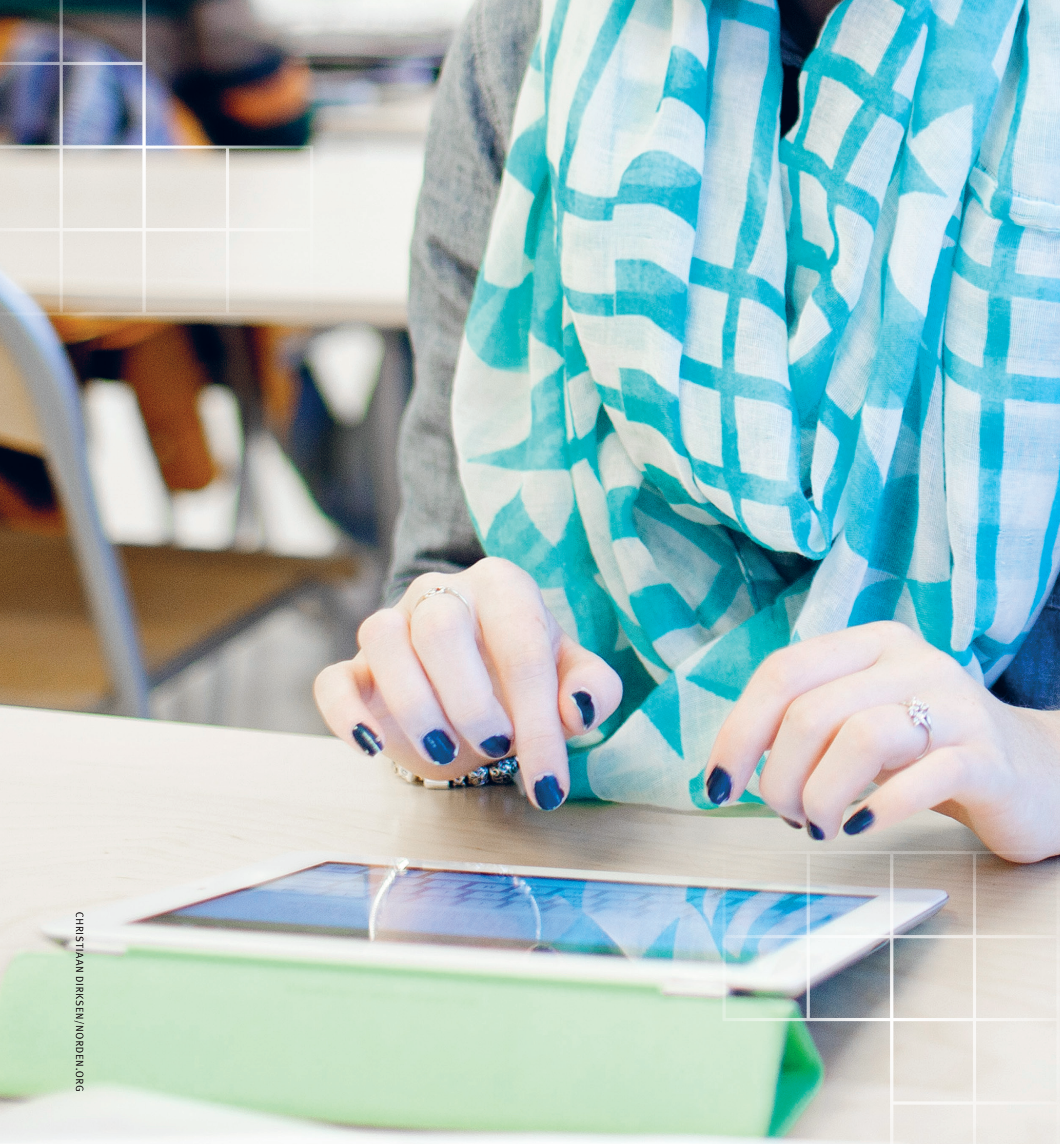




\section{Framtidsvägar och utvecklingsmodeller}

Frågan är nu hur Norden ska lyckas hantera de tre stora utmaningarna: den digitala revolutionen, globaliseringen och den ökande livslängden. Dessa trender utraderar jobb, ökar ojämlikheten, höjer offentliga utgifter, reducerar skatteinkomster och gör ekonomierna mer instabila. Kan den nordiska modellen överleva - eller kanske till och med utvecklas under dessa omständigheter?

Att säkert svara på denna fråga är knappast möjligt. Men trots det så vågar man nog besvara frågan med ett kvalificerat ja. Om man jämför Norden med andra utvecklade ekonomier, så kan det konstateras att Norden, trots många brister, generellt intar en god position. De nordiska länderna kan uppvisa en stark tradition när det gäller att anpassa sig till de ekonomiska tryck som strukturella förändringar medför. De har också lyckats att mobilisera en stor del av befolkningen i lönsamma ekonomiska verksamheter och uppvisat en produktivitet som ligger i världsklass.

Men det krävs också förändringar och förbättringar. Det

\section{$\frac{\mid}{\text { 1. Ökad satsning på kunskaps- och }}$ kompetensutveckling.}

Livslångt lärande och jämlik tillgång på undervisning ska vara ledstjärnor. Insatser i låg ålder är viktiga för att undvika problem i vuxenlivet. Därför måste man satsa starkt på barnomsorgen, förskoleverksamheten och grundskolan. Lärarkårens kompetens verkar vara en kritisk faktor när det gäller undervisningens resultat. Här spelar inte minst lärarnas ekonomiska position och sociala status en stor roll. Man bör vidare åstadkomma ett utbyggt lärlingssystem som tar vara på den begåvning som kanske inte kommer till sin rätt på gymnasienivån. På universitetsnivå ska den akademiska kvaliteten alltid ha den högsta prioriteten i olika situationer och överväganden. Senare i livet blir vuxenundervisningen och fortbildningen allt viktigare i ett samhälle där förändringarna inom kunskapsmassan och teknologin sker allt snabbare. Ökat lärande är inte bara viktigt för att kunna hantera förändrade förhållanden på arbetsmarknaden, utan ger också effekter på jämlikheten, tilliten och sammanhållningen i samhället. En hög kompetensnivå hos arbetskraften är en utomordentligt viktig faktor för att hävda sig i den globala konkurrensen. 


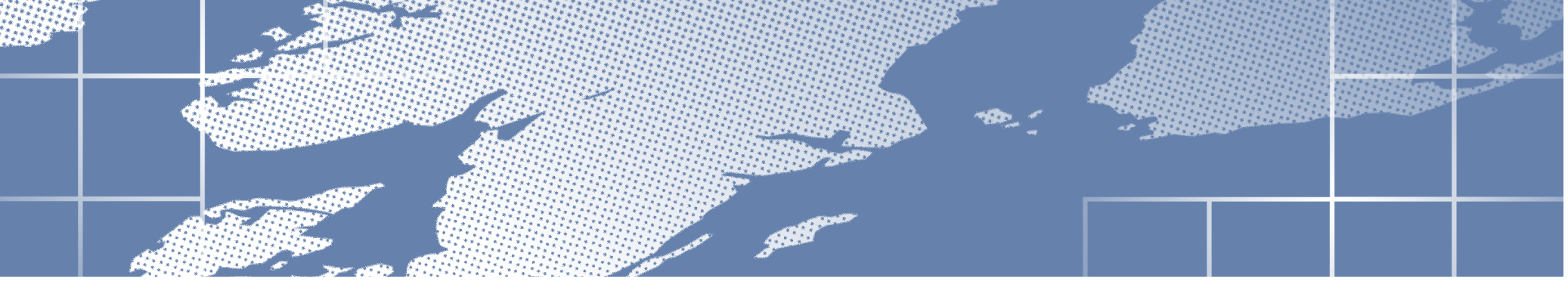

2. Kraftfulla åtgärder bör genomföras som minskar den negativa effekten på arbetskraftstillgången som den förändrade åldersstrukturen medför.

Den genomsnittliga pensionsåldern bör höjas i linje med den stigande förväntade livslängden. Välriktade reformer kan resultera i längre yrkeskarriärer, högre pensioner, bättre offentliga finanser och reducera fattigdomen bland äldre. Det finns också möjligheter att underlätta ett ökat kvinnligt deltagande i arbetsmarknaden. Vidare så bör universitetsstudenter via ekonomiska styrmedel lockas ut på arbetsmarknaden tidigare. Detta är ett område där Norden skiljer ut sig negativt. En annan nyckelfråga är att i högre grad få in utlandsfödda på arbetsmarknaden i hela Norden.

3. Att minimera arbetslösheten och att styra arbetskraften till de mest produktiva arbetena är de viktigaste målen för arbetsmarknadspolitiken.

På grund av de snabba tekniska förändringarna, den globala kompetenskonkurrensen och den höga makroekonomiska flyktigheten så är löneflexibilitet mycket viktig för att hålla ner arbetslösheten. Vissa ökande inkomstskillnader kan sannolikt inte undvikas om man siktar på höga sysselsättningsnivåer i framtiden. 
4. Man bör anstränga sig för att främja innovationskraften och förmågan till snabba strukturella omställningar.

Att acceptera "kreativ förstörelse" och hålla sig i frontlinjen i den globala tekniska utvecklingen är centralt för att upprätthålla en hög levnadsstandard. En effektivisering av hur de offentliga medlen används inom forsknings- och innovationsverksamheten är önskvärd. Att specialisera sig inom vissa fält av forskning och utveckling innebär alltid en risk, men är samtidigt nödvändigt för de i ett globalt sammanhang små nordiska länderna.

5. Det är knappast möjligt att öka den generella skattenivån i förhållande till BNP.

Frågan är snarare hur mycket skatterna måste minska, beroende på den ökande mobiliteten i de viktigaste skattebaserna. Det finns utrymme för förbättringar av strukturen i skattesystemen. Man bör stimulera arbetskraftsutbudet, arbetskraftens rörlighet, risktagande och deltagande i de globala värdekedjorna. Att minska skatten på arbete och istället öka den på egendom och konsumtion är önskvärt. Nivån på bolagsskatterna måste vara internationellt konkurrensmässig.

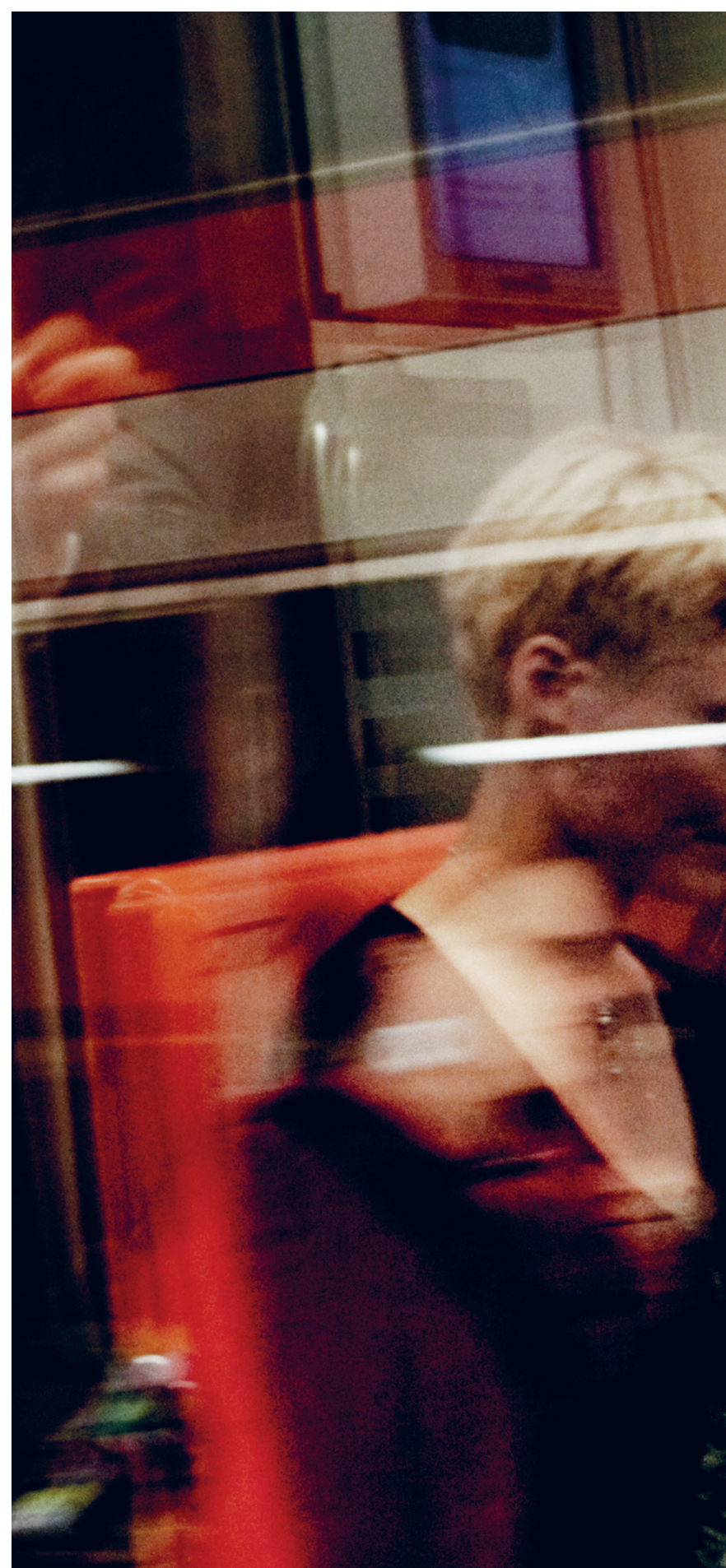




\section{Slutligen gäller det att inte förtröttas i ansträngningarna att effektivisera den offentliga sektorn.}

Även om Norden hävdar sig rätt väl inom detta område - jämförelser är svåra - så finns det många möjligheter till förbättringar i alla de nordiska länderna. Det finns inga enkla svar på hur man organiserar offentliga verksamheter mest effektivt, men framgångar kan uppnås genom ökat användande av marknadsmekanismer. Användande av ny digital teknik i offentlig förvaltning kan också ge betydande besparingar. Dessutom är det viktigt att förbättra metoderna för utvärdering av kvalitetsnivån hos de offentliga tjänsterna, vare sig de utförs av privata eller offentliga aktörer.

Sund makroekonomisk politik är en viktig grundförutsättning för ett fungerande samhälle. Erfarenheterna visar att en illa skött makroekonomi allvarligt kan skada ett land. Höga utlandsskulder och permanent hög arbetslöshetsnivå blir ett långvarigt arv som överlämnas till framtida generationer. Man måste alltid kontrollera att inte krediterna skenar och att bankerna håller sig innanför de uppsatta ramarna.
En nödvändig förutsättning för stabila finanser är att se till att det finns budgetutrymme för att hantera traditionella konjunktursvängningar. Det kan bli svårt även i de bästa tider - att bygga upp tillräckliga buffertar om trycket från den digitala revolutionen, globaliseringen och den ökande medellivslängden blir riktigt hårt. Dessutom kan det vara svårt att avgöra om en nedgång är cyklisk och fordrar överbryggande stimulansåtgärder eller om den är permanent och istället kräver anpassning till den nya situationen. Oberoende expertgrupper kan hjälpa till med avgöranden och se till att man inte bygger upp alltför stora skulder under nedgångsperioder. Erfarenheterna från sådana ekonomiska råd $\mathrm{i}$ Danmark och Sverige är på många sätt uppmuntrande. 


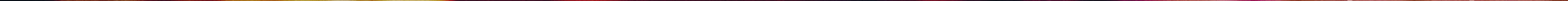




\section{De nordiska ländernas svagheter och styrkor samt förslag till åtgärder}

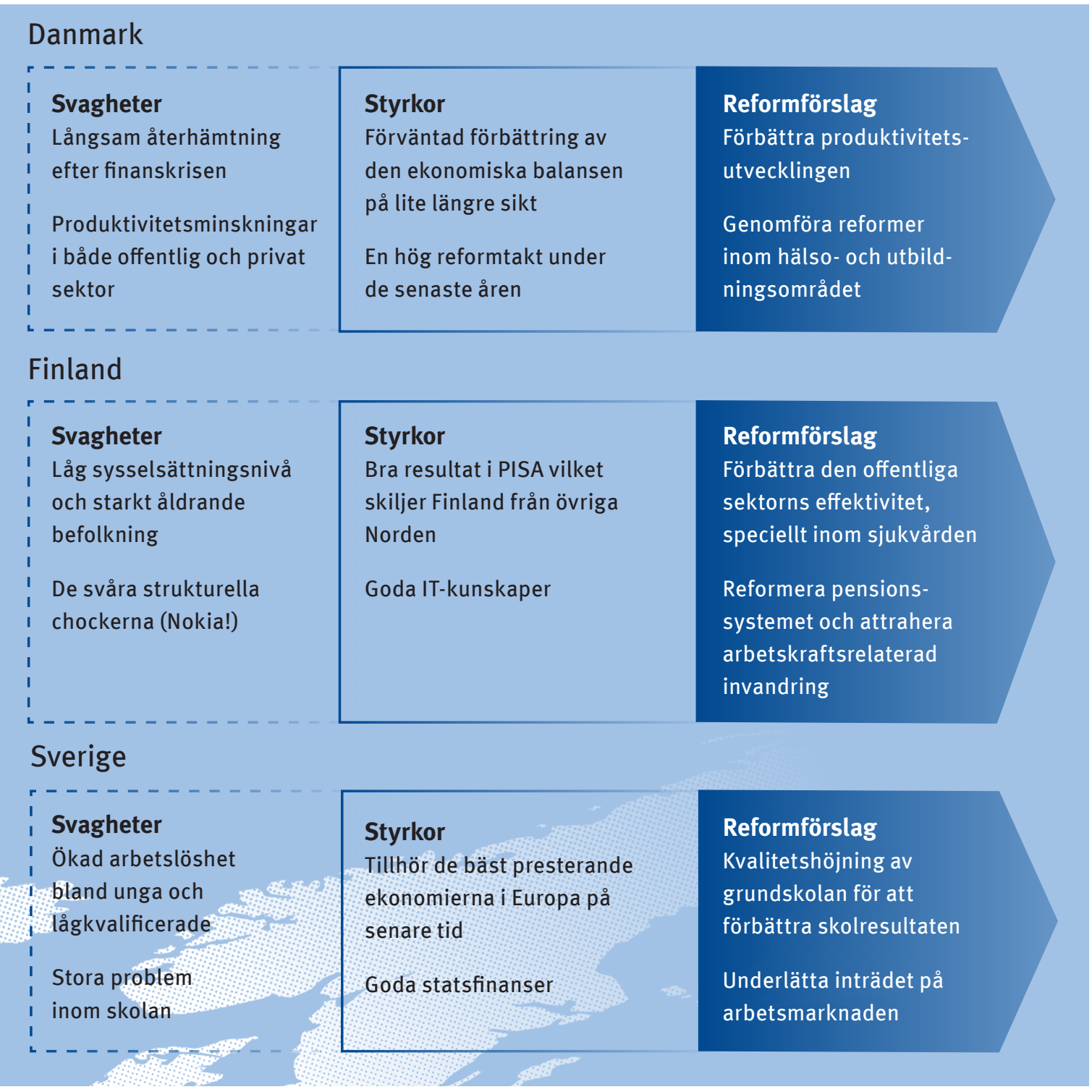




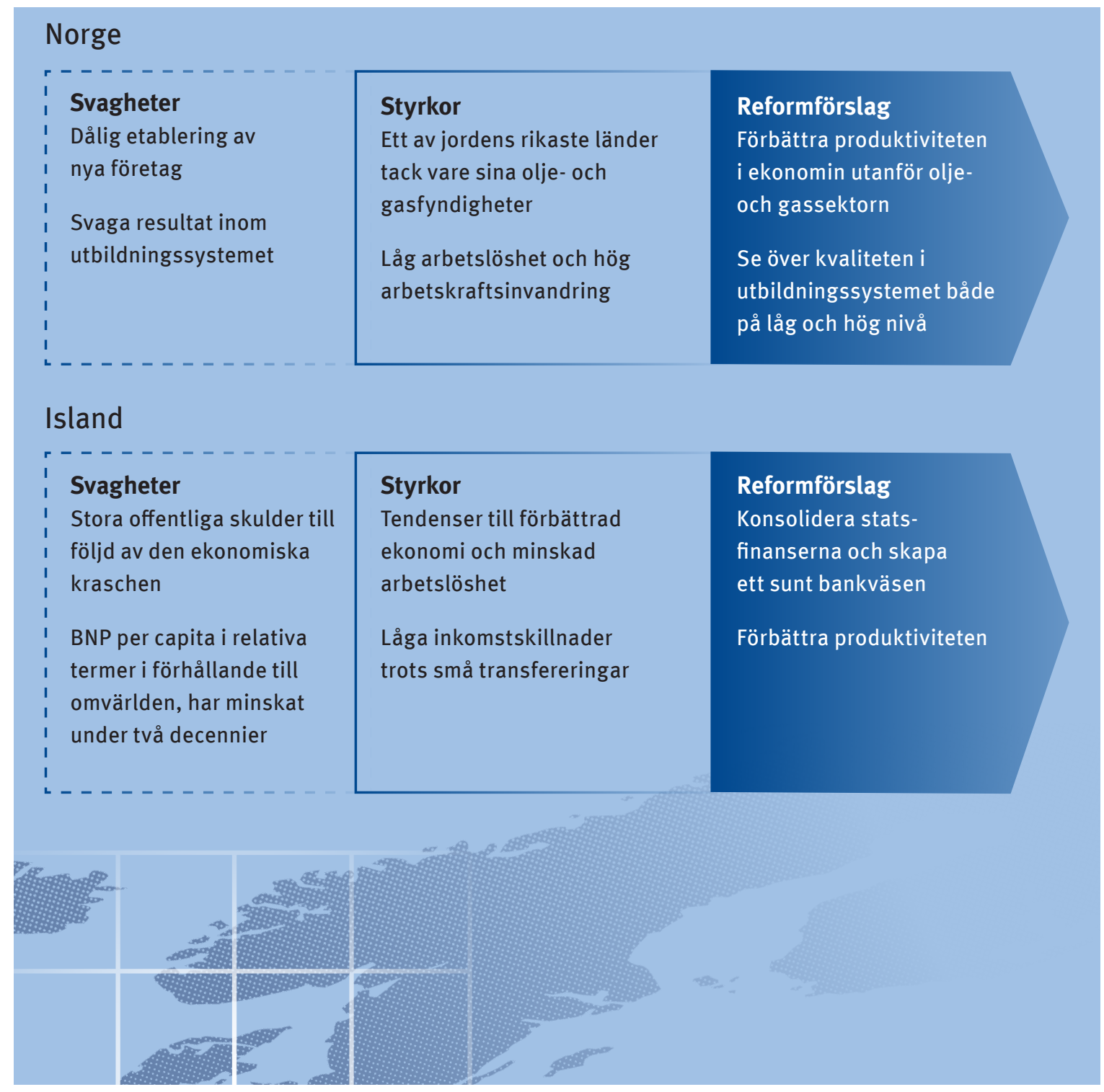




\section{Slutord}

Det är alltid politiskt svårt att genomföra reformer som är långsiktigt nödvändiga men smärtsamma i det korta perspektivet, speciellt som det är svårt att förutse det framtida utfallet av politiska åtgärder och reformer. Därför behövs en öppenhet inför nya idéer och metoder, men också en ödmjukhet och omprövningsvilja i takt med utvecklingen. Det är ovärderligt för ett samhälle att noggrant, kritiskt och mångsidigt ha förmågan att avläsa resultaten av politiska reformer, och därifrån dra slutsatser om den framtida färdvägen. De ovan föreslagna reformerna kommer med all sannolikhet att öka de nordiska ländernas förmåga att hålla nivån på, eller till och med öka, de höga sysselsättningstalen. Dessutom kommer de förhoppningsvis att leda till en produktivitetsökning som står sig väl i den internationella konkurrensen. En viss ökning av inkomstskillnaderna är dock troligen ofrånkomlig. Det beror på det starka trycket på en utvidgning av skillnaderna i marknadsinkomsterna på grund av den globala konkurrensen och den tekniska utvecklingen. Samtidigt kan transfereringar av inkomster inte ökas utan måste kanske snarare minskas. En sådan förändring behöver dock inte bli så stor om man kan fortsätta uppnå höga sysselsättningsnivåer och effektiviseringen av den offentliga sektorn blir framgångsrik.

Den nordiska modellen behöver inte nedmontering och rekonstruktion. Med en viss justering, finkalibrering och klarare fokusering kan den nordiska modellen fortsätta att vara framgångsrik. 

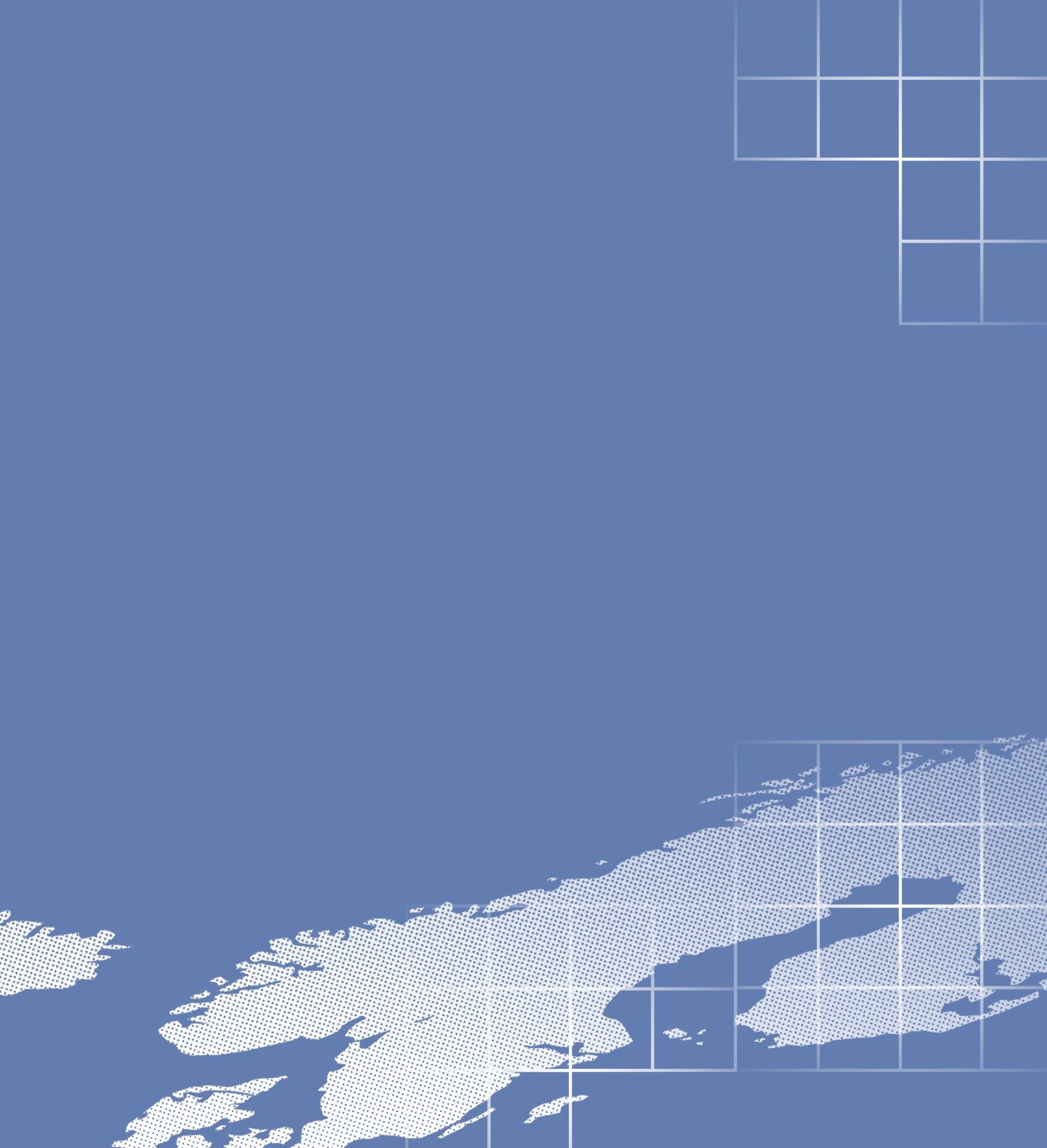


\section{norden}

Nordiska ministerrådet

Ved Stranden 18

DK-1061 København K

www.norden.org

\section{Behöver den nordiska modellen förändras?}

Den nordiska modellen är ett väl etablerat begrepp i världen. Den förklarar bland annat de nordiska ländernas framgångar under senare tid, inte minst vad gäller olika ekonomiska aspekter. Men hur fungerar modellen i den globaliserade samtiden och har den en framtid? Här beskrivs digitaliseringens, globaliseringens och den kantrande ålderspyramidens konsekvenser. Forskarna ger också förslag på vad som behöver reformeras i de nordiska länderna för att modellen ska ha en framtid. 